\title{
Research on Reconstructing of Our Country's Listed Companies' Independent Director System
}

\author{
Qiutao Shen \\ Management School \\ Shanghai University of Engineering Science \\ Shanghai, China \\ shenqt@wangfan.com
}

\begin{abstract}
Due to the listed companies in China a dominant equity structure, which contributed to the implementation of the independent director system far did not play its due, and urgently needs a reformation in system. As a new idea for independent director system, this paper discussed the necessity the independent directors registered system, the possibility of construction of registered independent director office, and discussed in detail the properties and functions of the registered independent director association.
\end{abstract}

Keywords-independent director; registered system; office; industry association; listed company

\section{INTRODUCTION}

Since August 2001 we have brought the independent director system of the listed company (hereinafter referred as independent director) from the US and England into our country, because of the dominant equity structures the independent directors have always been recommended by the major shareholders so that the independent directors cannot restraint their recommenders at all. Therefore, directly copying the independent director system of America and England which has been designed to solve the issues of equity separation and internal personnel will finally lead some disadvantages to the independent director in China such as "not being impendent", "immaturity" and "taking negative action". Hence, only by changing the "eye candy" status of the independent director, can we optimize the company's management structure.

The idea of improving the independent director system of listed company in China is to set up "Registered Independent Director Office" and establish a corresponding "Registered Independent Director Association" based on executing the independent director register system.

\section{THE REGULAR INDEPENDENT DIRECTOR AND THE REGISTERED INDEPENDENT DIRECTOR}

Independent directors are the core of the independent director system. Because the whole company and the independent directors are not clearly aware of their rights and obligations, the independent director is becoming a rootless system and losing its function.

The idea of improving the independent director system of listed company in China is to implement management classification according to the independent directors' functions.

\section{A. The Fundamental Functions of the Independent Director}

Firstly, management and consultation. Because of the professional knowledge and abundant experience the independent directors own, they can make decisions in some large strategic issues such as company's development, operation and resources allocation independently, make reasonable strategic plan and provide consultations.

Secondly, supervision and protection. In the absence of small and medium-sized shareholders, by endowing the independent directors privileges to supervise enterprises' managers (and major shareholders) and maintain the interests of the whole company, especially the rights of the small and medium-sized shareholders, which can check and balance the major shareholders and senior managers in the moral risk and power abuse.

In order to better performance the different obligation of the independent director, it's recommended to divide the directors into two categories to control

\section{B. Regular Independent Director}

The features of the regular independent director are: directors have professional knowledge and abundant experience in the strategic development of the listed companies; it is selected by the major shareholders and general meeting; its main obligation is "management and consultation"; nearly a part-time job; the number of the supervisors in the board of the director is not settled, but completely decided by the demand of the listed company itself.

\section{Registered Independent Director}

The features of the registered independent director are: directors have professional knowledge and abundant experience; qualified "Registered Independent Director"; attached to the shareholders' meeting, recruited by the directors in the "Registered Independent Selecting and Recruiting Committee; mainly perform "supervision and protection"; registered independent directors all work at full time (part-time job not allowed); the number of the supervisors in the board of the director is fixed. 
Because registered independent directors involve in the management and consultation, especially in making decisions, it's difficult for them to keep independence, consequently, they couldn't supervise the procedure of making decisions so that their supervision function is not effective. Taking that into consideration, the main function of the registered director in China should be positioned on supervision and protection.

Currently, the listed companies in China are more likely to choose university teachers or celebrities with high social status in order to gain a good reputation. They are theorists or experts in certain field but lack of experience of management, theoretical knowledge of supervision and practical experience to perform supervision. It is necessary to set up the registered independent director qualification system in order to guarantee directors' executive ability. The specific method is: The Registered Independent Director Association (attached to the Listed Company Association) is charge of the qualification exam, set the exam subjects (such as accounting, securities business, law and etc.) and the exam outline. They can get the certificate after pass the exam and relevant approval. After that, they can be an independent director; what's more, independent directors often play multiple roles and they don't have enough time and energy to understand the company operation. So by making the directors who are in charge of supervision more professional, they can be the backbone in the listed companies in China by associating with layers and accountants.

At the same time, in order to push forward the professionalism and marketing process of the registered independent director, play its group utility, and keep its independence help to build up proficient incentive and control mechanism. It's suggested to set up a "Registered Independent Director Office" as similar as the Law Office and the Accounting Firm

\section{ESTABLISHMENT OF REGISTER INDEPENDENT DIRECTOR OFFICE}

In order to promote the professionalism and marketization of registered independent director office, as well as play the role of registered independent director, ensure the organizational independence of it and set up corresponding effective incentive and restraint mechanism, it is a practical way to establish registered independent director office, which independently enjoys civil rights and assumes civil obligations.

\section{A. The Establishment of Independent Director Office is Conductive to the Professionalism and Marketization of Registered Independent Director Office}

The establishment of office corporatizes the independent director that registered by natural persons, which is in favor of socialization, professionalism and marketization of registered independent director business. It will not only avoid the dispersed registered independent directors as "stragglers", but also brings them professional sense of belonging. On the other hand, the key link to ensure the independence of independent directors in participating and supervising the decision-making process of listed companies is walking out the mode that the independent directors are recommended to work in the companies through interestrelated persons. And offices, as intermediary, will exactly ensure that the independent directors are chosen into the listed companies through fully market-oriented mechanism. Thus, it will be able to solve the problems of independent directors from mechanism, that is, the independence, objectivity and impartiality.

\section{B. The Establishment of Registered Independent Director Office Will Make the Registered Independent Directors Group Work Effectively}

In order to effectively exercise the protection and supervisory functions to listed companies, registered independent directors are always required to own solid theoretical knowledge and rich experience in practice about one or more respects of legislation, accounting, finance, science, engineering, management and so on, that means they should be experts in some aspects. However, none of the registered independent directors is an overall genius. Establishing registered independent director office will cover the shortages of single registered independent director because the teams in office, which are composed of professional managers, investment experts, attorneys, accountants and other professional experts, will support them. Registered independent directors will be able to have a discussion in office when the listed companies face issues about interest of minority stockholders or have important pre-arranged plans to vote and then make decisions after acquiring the experts in office. In this way, the shortages of registered independent directors are made up and the offices effectively play their role as a team.

\section{The Establishment of Registered Independent Director Office is Conductive to Excise Their Functions and Powers}

The independent directors should be independent to carefully execute their duties and make objective judgments. Establishing independent director office is an effective way to secure their independence. If an independent director wants to be a part of the board of a listed company, he or she will be recommended directly by the office, affirmed by China Securities Regulatory Commission ( CSRC) and passed by the board. The payment of all the registered independent directors in listed companies will not be paid by the companies. Instead, the office will charge for management fee from listed companies then pay for the working registered independent directors. The rest part of the fee will become cost of offices for personnel information collection, reserving, training, communication and daily management. The advantage of this is to ensure the independence of registered independent directors.

\section{The Establishment of Registered Independent Director Office Will Set Up Corresponding Effective Incentive and Restraint Mechanism}

It is necessary to complete the incentive mechanism for independent directors to ensure their effective operation. 
Establishing office is a good solution. On the base of regular supervision, inspection and assessment of the independent directors' duty, the office will pay them based on their performance. To strengthen restraint on the independent directors' behavior, the office should bear joint civil liability when independent director brings damage to its companies or stockholders due to its own responsibility. The independent director and the office he or she belongs compensate the damage and receive punishment together. Thus, the independent directors will no longer only work of their own consciousness. Their performances are guaranteed in the organization, system and laws.

\section{E. Operation Mechanism of Registered Independent Director Office}

Referring to the management mechanism of law office and accounting firm, the new-established registered independent director office is a kind of self-financing intermediary service agency registered in Administration for Industry and Commerce, spontaneously set up by registered independent directors, carrying out independent businesses in accordance with the law. Office can be established by registered independent directors jointly. Under certain conditions, it also can be a legal person gives its owners limited liability.

Office purpose: adaption to reform and opening and meet the needs of establishing socialist market economy system; giving full play to independent directors' role in decision-making, supervision in economic activities; strictly observing independence, justice and objectivity principle; safeguarding the interest of both independent director and listed companies.

Office operation target: Realizing the maximum market value of office by providing a series of high-quality intermediate service to listed companies.

Office business scope: a. Recommending registered independent director to the board of listed companies (core business); b. Recommending common independent director to listed companies and unlisted companies; c. Real-time monitoring and evaluating registered independent directors and common independent directors of enterprises under their delegation; d. Providing consultation and training for enterprises of independent directors; e. Any other businesses of consignors

Office operation mechanism:

1) Two-way selection and hiring between registered independent directors and listed companies under the coordination of office

The designed basic procedure as follow: To avoid the single-large shareholder in listed companies, it is suggested that " Registered independent director election committee" (mainly composed of qualified registered independent directors), which belongs to general meeting of shareholders and is on behalf of the interest of minority shareholders, puts an invitation (or competition) request to registered independent director office attached detailed invitation (or competition) materials including invitation letter (or competition letter), the resolutions of shareholders' meeting and so on. After consideration, the office replies and organizes two-way selection between listed company and recommended registered independent director in public. The listed company signs an agreement with the office and at the same time, issues employment letter to the chosen registered independent director. This agreement is enforceable which means the listed company should grant corresponding rights to the employed registered independent director in decisionmaking and the registered independent director should comply with its duty and responsibility.

2) Management cost and salary incentive mechanism of registered independent director office

Registered independent directors should be ranked according to their professional qualification and work achievement. Differences on scale, professional quality and degree risk of listed companies determine the complexity level of independent directors while participating in companies affairs. So it is suggested that "Registered independent director committee" demands different listed companies hire registered independent director in different levels and the management cost also varies.

The management cost can refer to the charging standards of listed company executive director and registered independent director industry, charging to listed companies as written in the contracts.

3) Office supervision and assessment on registered independent directors

For the purpose of safeguarding the interests of independent directors and the office, the sent-out registered independent directors should be real-time monitored about their competence, integrity and performance. Especially, the office has to prevent the independent directors from conspiring with strong stock holders and company management to damage the interests of minority shareholders as well as their moral hazard and abuse of power for personal gain and big mistakes due to their scarce capacity or misconduct in office.

In order to effectively assess the registered independent directors, the office has to set up position statement for them, analyzing and describing the rights, obligations and responsibilities of independent directors in details and editing Registered Independent Director Workbook. On this basis, the office should establish a rounded system, including assessment process and objectives, making objective assessment from personal quality and work performance with quantizable performance indicators. The office will regularly report the assessment results to related corporate shareholders and "Registered independent director election committee". To some problem independent directors, the office should report to the committee in time. After investigation, the office will make punishment to the registered independent directors from criticism, demotion to disqualification depending on the seriousness.

To make effective management of listed company registered independent directors and independent director office, corresponding industrial administrative organizations should be founded under this base. 


\section{ESTABLISHING THE REGISTERED INDEPENDENT DIRECTOR ASSOCIATION}

The Registered Independent Director Association (hereinafter referred as "the Association") is a social organization consist of registered independent directors, the Registered Independent Director Office and the listed company. It is lead by the China Securities Regulatory Commission Investor Protection Bureau and belongs to "Listed Company Association". The Association is also a self-regulatory organization and control the independent directors work performance according to the law.

\section{A. Membership of the Association: Corporate Member and} Individual Member

Corporate member: legally established Registered Independent Director Office, the listed companies.

Individual member: people who pass the independent director exam and get the professional qualification certificate.

\section{B. Purposes of the Association: Serve, Supervision, Coordination}

Namely, based on the integrity construction, it serves for the members, supervises their work performance and morality, executes register industry management, coordinates the internal and external relationships, maintain the legal rights of the shareholders, other relevant people and members, and push the industry to develop in a scientific way.

\section{Responsibilities of the ASSOCIATION}

1) Annual inspection on the qualification of the independent directors and the work performance

2) Making the industrial regulation, punishing the members who violate the applicable laws and industrial regulation

3) Organizing the registered independent directors exam

4) Building up the directors human resource organization; promoting the training of the member and industrial human resource construction

5) Organizing business and theories seminar; providing technical supports

6) Promoting the registered independent directors industry

7) Coordinating the internal and external relationships; supporting the member to work legally and maintaining their legal rights

\section{Funding of the Association}

1) Membership fees

2) Appropriation from the China Securities Regulatory Commission Investor Protection Bureau

3) Social donation

4) Other legal income
E. The Structure of the Association: the Supreme Power is the Membership Representative Congress Which Elects the Council

The council elects president, vice president and the executive council. The council comprises several special committees and professional committees. The executive council will exercise the function and power of the council when the council is not in session. The association sets secretariat as its standing executive body.

The council could consist of strategic committee, the registered independent director business criterion and code of professional ethics committee, finance committee, discipline board, appeal and rights protection committee, training and teaching committee, register administration committee, operation responsibility evaluation committee, independent director office internal governance instruction committee and professional skill instruction committee.

The association should actively explore the principles of industry management, strengthen the function constructions in terms of service, supervision, management and coordination facing the registered independent directors, and complete the industrial management and service system. The systems includes the service-oriented registered independent director engagement system to the listed companies, competence-oriented examination and evaluation system, the standard register entrance system orients to setting the entering threshold, the lifelong learning-oriented continuing education, honesty and morality oriented and operation quality oriented supervision and inspection system, the development strategy system orients to a bigger and stronger industry and service, supervision, management and coordination oriented industrial organization system.

In a conclusion, through the reconstruction of Our Country's Listed Companies' Independent Director System, the independent director recruiting and selecting system will become impeccable, the effective incentive and restraint mechanism will set up. On the base of independence of independent directors, they will balance the strong shareholders and the board under their control and play a further role of them in management of our country's listed companies.

\section{REFERENCES}

[1] Lu Qiang, "Thinking on the establishment of independent director register system," Journal of Hunan Business College, 2003,vol.3. pp.68-73.

[2] Zhang Xiaoming, Li Hui, Li Liaoning, "Exploration on establishing marketized independent recruiting and selection system," Journal of Xidian University (Social Science Edition), 2011, vol.1, pp. 271-350.

[3] Zhou Xiaohong, Dai Rui, "Brief analysis on expectations of our country' s independent director functions," Commercial Accounting, 2011, vol. 10, pp. 74-77.

[4] Lei Lihua, "Brief analysis on function orientation of our country' s independent director," Technological Development of Enterprise, 2009,vol.3, pp. 8-15.

[5] Sun Jingshui, "Aphorism on the establishment of independent director association," Science \& Technology Progress and Policy, 2003, vol.7, pp. 45-50 
[6] Zeng Xianrong, "The Establishment of Independent Director Office is a Great Measure of Perfecting Independent Director System," Modern Enterprise, 2004, vol.8, pp 65-70. 